\title{
Fertility and Effective Population Size in Seedling Seed Orchards of Casuarina equisetifolia and C. junghuhniana
}

\author{
By M. VARGHese ${ }^{1,2}$, D. LINDGReN ${ }^{1}$ and A. NiCODEMUS ${ }^{2}$
}

(Received $1^{\text {st }}$ July 2004)

\begin{abstract}
Two seedling seed orchards each of $C$. equisetifolia and $C$. junghuhniana established by thinning provenance trials in coastal and inland locations in South India were evaluated for sex expression and fertility variation at four years. More than $80 \%$ of the trees in C. equisetifolia orchards were fertile in both sites with a similar pattern of more (almost 2 times) female trees and equal proportion of monoecious and non-flowering trees. In C. junghuhniana, the coastal orchard had twice the proportion of fertile trees as that of the inland.

Orchards established in coastal environment had less fertility variation and hence maintained lower coancestry values in both species. Coastal site has more trees contributing effectively to seed production than inland locations and the orchards maintain higher (almost two times) effective population sizes. Genetic drift is also 3 times higher in inland locations in both species. Male and female trees in inland orchards of both species however had greater reproductive output than coastal trees. Monoecious Casuarina equisetifolia trees showed a different trend of greater male fertility in coastal site, but seed output was the same in both locations. Gene diversity values of all orchards are high though it is marginally higher in coastal sites. Measures like constrained seed collection from large number of trees and promoting representation of superior provenances with low fertility would be useful in checking diversity loss during domestication.
\end{abstract}

Key words: breeding population, coancestry, gene diversity, relative status number, provenance trial, seed orchard.

\section{Introduction}

Casuarina equisetifolia Forst. is extensively planted in the eastern coast of India as a short rotation tree crop mostly for use as poles and pulpwood. Introduced over a century ago, the seed source is believed to have originated from a narrow base and developed into a land race domesticated mostly by farmers. Evaluation of several native provenances and land races was taken up in India and other South East Asian countries during the last decade. Provenance trials and breeding populations were established for identifying promising varieties (PINYOPUSARERK et al., 1996) and production of improved seed for planting. Casuarina junghuhniana Miq. which is native to Indonesia was also newly introduced and tested in two locations and found to be a promising species for afforestation and pulpwood production in India (NICODEMUs et al., 2001a).

Casuarina is grown in high density plantations (ca. 10000 stems ha ${ }^{-1}$ ) under short rotations of 4 to 6 years. A large quantity of seed is needed every year to meet planting stock demand. Seedling seed orchards are the popular production populations because of easy establishment and early seed production (four to five years). Accordingly breeding populations and provenance/progeny trials were designed to be converted into seed orchards in an ongoing breeding programme (PINYO-

\footnotetext{
1) Department of Forest Genetics and Plant Physiology, Swedish University of Agricultural Sciences, SE 901 83, Umea, Sweden.

2) Institute of Forest Genetics and Tree Breeding, Coimbatore - 641002, India.
}

PUSARERK, 1996), after early evaluation and elimination of inferior trees.

Casuarina is wind pollinated with variation in sex expression in different populations. Most populations are predominantly dioecious with few monoecious individuals. Differences between ramets of the same clone (LuECHANIMITCHIT and LUANGVIRIYASAENG, 1996; WARRIER et al., 2001) as well as significant region and provenance effects (LUECHANIMITCHIT, 2002; NAGARAJAN et al., 2001) in sex expression are reported in C. equisetifolia. Sexes are separate in C. junghuhniana, without monoecious trees (PINYOPUSARERK and BOLAND, 1990).

As per the breeding programme, provenance trials were converted to seedling seed orchards at four years. These first generation orchards are probably the first attempt to domesticate natural casuarina germplasm in South India. Huge fertility variation is reported between provenances (PINYOPUSARERK and WILLIAMS, 2000) but information on quantum of seed produced and diversity of progeny from Casuarina seed orchards is meagre. A study on fertility status of trees retained in orchards was taken up and flower and seed production estimated for each tree. This paper pertains to analysis of fertility variation in seedling seed orchards of two species of Casuarina and its impact on gene diversity of seed crop.

\section{Theory and Methods}

The theoretical background for seed orchards utilized in this study was developed by LINDGREN and MULLIN (1998) and KANG et al. (2001). Group coancestry $(\Theta)$ is the probability that two genes taken at random from the gene pool of the expected seed orchard crop will be identical by descent. Group coancestry applied for a diploid population is the average of all coancestry values between population members (including self-coancestry), but as group coancestry depends only on the gene pool and not how the genes are organized into individuals, the group coancestry concept can as well be applied to successful gametes before they form diploid zygotes (LINDGREN and MulLin, 1998). Status number $\left(N_{s}\right)$ is the number of non inbred non related genotypes sampled from the reference population that are expected to experience the same deviation in gene frequencies from the reference population as the population under study. These two parameters are used to monitor the diversity level in the orchard resulting from relatedness of selected trees. Sibling coefficient $(\Psi)$, which is the probability that two genes originate from the same parent, is used to quantify the extent of fertility differences between orchard genotypes. Maternal and paternal fertilities of each tree are used as the probability of contribution of each genotype in determining the group coancestry $(\Theta)$.

Group coancestry: As an expression of the accumulated loss of gene diversity, group coancestry can be estimated relative to the reference population. The reference population is defined as having an infinite number of unrelated individuals, and thus a group coancestry of 0 and gene diversity of 1 (KANG and LINDGREN, 1999). In a seed orchard with finite number of related individuals, as described by LINDGREN and MulLiN 
(1998), the group coancestry of seed orchard crops $(\Theta)$ is given by

$$
\Theta=\Sigma p_{i} p_{j} \theta_{i j}
$$

where, $p_{i}$ (or $p_{j}$ ) is proportion of tree $i$ (or $j$ ), and $\theta_{i j}$ is coancestry between tree $i$ and $j$.

Status number effective population size: It is convenient and understandable to characterize a seed orchard by an "effective number". Status number is such a number. For an ideal seed orchard where the fertility of the entries is constant and there is no inbreeding or relatedness or migration, status number of the seed orchard crop and census number is the same.

Status number is half the inverse of group coancestry.

$$
N_{s}=\frac{0.5}{\Theta}
$$

When the seed orchard trees are considered non inbred and non related, status number can be calculated as

$$
N_{s}=\frac{1}{\sum_{i=1}^{N} p_{i}^{2}}
$$

where $p_{i}$ is the contribution from individual genotype $i$ to the gamete pool and $N$ the census number of trees in the orchard.

Relative status number $\left(N_{r}\right)$ was used to compare the effective number of trees contributing to random mating with the actual number of trees retained in the orchard.

$$
N_{r}=\frac{N_{s}}{N}
$$

Variance effective population size $\left(N_{e}^{(v)}\right)$ : It describes the size of the population that would give the same drift in gene frequencies as that which occurs between the seed orchard genotypes and their seed crop. It can be calculated from sibling coefficient and coancestry values (KANG et al., 2001)

$$
N_{v}^{(v)}=\frac{\psi}{2 \Theta(\psi-1)}
$$

\section{Gene diversity}

Expected gene diversity $(G D)$ is a function of the group coancestry and can be calculated in the orchard relative to a reference population. The reference population, which is the natural forest, has zero group coancestry as it is considered to have infinite number of unrelated individuals.

$$
G D=1-\Theta
$$

Thus group coancestry can be regarded as the fraction of gene diversity lost.

Sibling coefficient $(\Psi)$ : It is calculated from the number of fertile trees in the orchard $(N)$ and individual fertility $\left(p_{i}\right)$ of each tree and used to describe fertility variation among the trees.

$$
\psi=N \sum_{i=1}^{N} p_{i}^{2}
$$

Maleness index: The maleness index based on production of male and female flowers is calculated (KANG and LINDGREN, 1999) from the proportions of male $\left(p m_{i}\right)$ and female $\left(p f_{i}\right)$ flowers produced by each $\left(i^{t h}\right)$ tree

$$
M_{i}=\frac{p m_{i}}{p f_{i}+p m_{i}}
$$

\section{Material}

Two orchards each of Casuarina equisetifolia and C. junghuhniana located in coastal (Pondicherry-Pondy) and inland (Karunya and Panampally respectively) regions in
South India were used for the study. Among these, three orchards (except the inland orchard of $C$. equisetifolia) were established initially as provenance trials in randomised complete block design (RCBD) with bulk seedlots of natural provenances and land races. The provenance trials were established as 25 tree plots of bulk seed collections from more than 25 parent trees each (PINYOPUSARERK, 1996). The inland C. equisetifolia orchard (Karunya) was established as a provenance - progeny trial of 100 families (from the same provenances as the other orchards) in RCBD with small plots (4 trees) for conversion to seedling seed orchard. First thinning was taken up in this trial at two years of age to eliminate two inferior trees in each plot. A second thinning was carried out at four years (when trees were old enough to express their sex (PINYOPUSARERK, 1996) and $70 \%$ of the trees were observed to be fertile in the trial) to retain the best trees and reduce stocking for good seed production. Nearly all trees in the worst $25 \%$ families were removed after evaluation (NICODEMUS et al., 2001b).

In the provenance trials thinning was carried out to remove inferior trees and provenances. Provenances like Guam, Fiji and Egypt were removed in C. equisetifolia, and best trees in outstanding natural provenances like Thailand, Solomon Islands and Papua New Guinea were retained (NICODEMUs et al., 2001b). Among land races Kenya, China and India were promising. In the replicated provenance trails of C. junghuhniana, seedlots of $C$. junghuhniana subspecies timorensis from Timor and Wetar islands of Indonesia were found to be superior to $C$. junghuhniana subspecies junghuhniana which were from higher altitudes and hence completely eliminated from the orchards (Nicodemus et al., 2001a). The orchards were planned to have a stocking of 200 to 250 trees per hectare after thinning for seed production. Some C. equisetifolia trees were affected by blister bark disease (NARAYANAN et al., 1996) in the inland orchard, which reduced the stocking in the site.

Seedling seed orchards were evaluated for individual tree fertility at age four when the trees were suitable for seed production. Sufficient spacing between trees was ensured for uniform conditions of flowering and seed set. Trees were assessed for sex, number of fruits and number and length of male inflorescences for estimating male and female fertility of each tree (VARGHESE et al., 2002). The number of primary, secondary and tertiary branches was counted in each tree and the flowers per tertiary branch recorded for all the trees. Number of fruits per secondary branch was recorded and estimates of fruits and flowers produced per tree were obtained by extrapolating the counts made on flowers and fruits (BILA et al., 1999; KANG and LINDGREN, 1998).

Details of site and stocking are provided in Table 1 and 2. More information on growth performance of provenances can be found in NiCODEMUS et al. (2001a and b).

\begin{tabular}{|c|c|c|c|c|}
\hline Trait & $\begin{array}{l}\text { C. equisetifolia } \\
\text { Karunya } \\
\text { (inland) }\end{array}$ & $\begin{array}{l}\text { C. equisetifolia } \\
\text { Pondy (Coast) }\end{array}$ & $\begin{array}{l}\text { C. junghuhniana } \\
\text { Panampally } \\
\text { (inland) }\end{array}$ & $\begin{array}{c}\text { C. junghuhniana } \\
\text { Pondy (Coast) }\end{array}$ \\
\hline Latitude & $11^{10} 00^{\circ}$ & $11^{0} 55^{\circ}$ & $10^{\circ} 52^{\circ}$ & $11^{0} 55^{\circ}$ \\
\hline Longitude & $76^{11} 58$ & $79^{\circ} 52$ & $76^{\circ} 46^{\circ}$ & $79^{\prime \prime} 52$ \\
\hline Rainfall (mm) & 1000 & 900 & 1200 & 900 \\
\hline Altitude (masl) & 300 & msl & 400 & $\mathrm{msl}$ \\
\hline Soil type & Clay loam & Sandy & Clay loam & Sandy \\
\hline $\begin{array}{l}\text { Temperature } \\
\text { range }\left({ }^{\circ} \mathrm{C}\right)\end{array}$ & $20-36$ & $21-38$ & $22-39$ & $21-38$ \\
\hline
\end{tabular}

Female inflorescences in Casuarina occur axially or on the primary branch and develop into cones with about 30-40 seeds per cone. Male inflorescences are borne terminally on needle like deciduous branches bearing about 39 flowers per centimeter length of the inflorescence. Monoecious trees often have short male inflorescences (NAGARAJAN et al., 2001).

Table 1. - Location, edaphic and climatic details of orchard sites. 
Table 2. - Gender pattern in seedling seed orchards (area = 1 ha).

\begin{tabular}{|c|c|c|c|c|}
\hline Trait & $\begin{array}{l}\text { C. equisetifolia } \\
\text { Karunya }\end{array}$ & $\begin{array}{l}\text { C. equisetifolia } \\
\text { Pondy }\end{array}$ & $\begin{array}{l}\text { C. junghumiana } \\
\text { Panampally }\end{array}$ & $\begin{array}{l}\text { C. junghuhniana } \\
\text { Pondy }\end{array}$ \\
\hline No. of trees & 190 & 255 & 214 & 269 \\
\hline $\begin{array}{l}\text { Male trees } \\
\qquad \text { (infl len- } \mathrm{cm})\end{array}$ & $\begin{array}{l}49 \\
(1.59)\end{array}$ & $\begin{array}{l}67 \\
(1.80)\end{array}$ & $\begin{array}{l}42 \\
(5.24)\end{array}$ & $\begin{array}{l}127 \\
(2.74)\end{array}$ \\
\hline Female trees & 84 & 124 & 55 & 139 \\
\hline $\begin{array}{l}\text { Monoecious trees } \\
\quad \text { (infl len - cm) }\end{array}$ & $\begin{array}{l}26 \\
(0.85)\end{array}$ & $\begin{array}{l}32 \\
(1.61)\end{array}$ & $\begin{array}{l}0 \\
-\end{array}$ & 0 \\
\hline $\begin{array}{l}\text { Maleness index } \\
\text { of monoecious trees }\end{array}$ & 0.391 & 0.645 & - & - \\
\hline Non flowering trees & 31 & 32 & 117 & 3 \\
\hline
\end{tabular}

(infl len- cm) - Length of male inflorescences in $\mathrm{cm}$.

\section{Results and Discussion}

A comparative analysis of Casuarina equisetifolia orchards in coastal and inland locations reveals a similar proportion of fertile trees -87 and $84 \%$ respectively. C. junghuhniana orchards however differed between locations showing very high frequency $(99 \%)$ of fertile trees in the coastal site whereas many trees $(55 \%)$ did not flower in the other location (Table 2). Female trees were more in number in C. equisetifolia and only about $13 \%$ trees were monoecious in both sites. There were only dioecious and no monoecious trees in C. junghuhniana.

\section{Fertility variation}

Male and female trees had greater reproductive output in the inland location in both species. While male trees of inland orchards produced three times more flowers in both species, fruit production per tree was $67 \%$ higher in C. equisetifolia and $35 \%$ more in $C$. junghuhniana inland orchards. Monoecious $C$. equisetifolia trees produced the same quantity of fruits in both sites but showed an opposite trend of greater $(65 \%)$ male reproductive output in coastal site (Table 3 ). This resulted from the fact that male inflorescences in coastal monoecious trees were almost twice as long as those of inland trees (Table 2). Inflorescences of male $C$. equisetifolia trees did not differ much between locations whereas in $C$. junghuhniana, inland trees had comparatively long male inflorescences $(5.24 \mathrm{~cm}$ as against 2.74 of coastal trees).

Table 3. - Reproductive output (per tree) and expected contribution (proportion) to the successful gametes in Casuarina orchards.

\begin{tabular}{l|cc|cc|ccc}
\hline \multirow{1}{*}{ Orchard } & \multicolumn{2}{|c|}{ Male } & \multicolumn{2}{c|}{ Female } & \multicolumn{3}{c}{ Monoecious } \\
\cline { 2 - 8 } & Prop & $\begin{array}{c}\text { Flowers/ } \\
\text { tree }\end{array}$ & Prop & $\begin{array}{c}\text { Fruits/ } \\
\text { tree }\end{array}$ & Prop & $\begin{array}{c}\text { Male } \\
\text { flowers/tree }\end{array}$ & $\begin{array}{c}\text { Fruits/ } \\
\text { tree }\end{array}$ \\
\hline $\begin{array}{l}\text { C. equisetifolia } \\
\text { Karunya }\end{array}$ & $46 \%$ & 3094164 & $41 \%$ & 3262 & $13 \%$ & 533437 & 2186 \\
$\begin{array}{l}\text { C. equisetifolia } \\
\text { Pondy }\end{array}$ & $35 \%$ & 967023 & $39 \%$ & 1953 & $26 \%$ & 877628 & 2113 \\
$\begin{array}{l}\text { C. junghuhniana } \\
\text { Panampally }\end{array}$ \\
$\begin{array}{l}\text { C. junghuhniana } \\
\text { Pondy }\end{array}$ & $50 \%$ & 4974631 & $50 \%$ & 3991 & - & - & - \\
\hline
\end{tabular}

Sibling coefficient $(\Psi)$ values, which give an estimate of fertility variation and thereby the extent of deviation from random mating, were similar for the two species at Pondy (Table 4). The values however differed between coastal and inland sites in both species indicating substantial deviation from random mating (6-7 times as indicated by $\Psi$ ) in the inland location (Table 4). Fertility proportions of male and female trees did not differ much between these locations (Table 3) but the gamete contribution of monoecious $C$. equsietifolia trees in coastal site was twice as that in the inland location (even though the percentage of monoecious trees were the same in both orchards). This actually resulted from low male output of monoecious trees in the inland location as indicated by low maleness index (quantified based on the male and female fertility of the monoecious trees relative to the entire orchard) of Karunya trees (Table 2).
Table 4. - Estimates of group coancestry, effective number, sibling coefficient and gene diversity in four seedling seed orchards of Casuarina.

\begin{tabular}{|l|l|l|l|l|}
\hline Trait & $\begin{array}{c}\text { C. equisetifolia } \\
\text { Karunya } \\
(\mathrm{n}=190)\end{array}$ & $\begin{array}{c}\text { C. equisetifolia } \\
\text { Pondy } \\
(\mathrm{n}=255)\end{array}$ & $\begin{array}{c}\text { C. junghuhniana } \\
\text { Panampally } \\
(\mathrm{n}=214)\end{array}$ & $\begin{array}{c}\text { C. junghuhniana } \\
\text { Pondy } \\
(\mathrm{n}=269)\end{array}$ \\
\hline$\Theta$ & 0.0153 & 0.0054 & 0.0165 & 0.0055 \\
\hline$N_{S}$ & 32.59 & 91.49 & 60.64 & 90.66 \\
\hline$N_{r}$ & 0.172 & 0.359 & 0.283 & 0.337 \\
\hline$N_{e}(v)$ & 39.34 & 142.69 & 35.32 & 136.75 \\
\hline$\Psi$ & 5.83 & 2.79 & 7.06 & 2.97 \\
\hline$G D$ & 0.985 & 0.995 & 0.984 & 0.995 \\
\hline
\end{tabular}

Fertility variation in $C$. junghuhniana was very high in the inland orchard (as indicated by $\Psi=7.06$ - Table 4), a contributing reason may be that many trees were not flowering at all (Table 2). KANG et al. (2003a) reported an average $\Psi$ value of 2.62 for seed orchards of broad leaved species, thus the fertility variation found on inland sites in this investigation may be regarded as unusually high, though high fertility differences have been reported in E. tereticornis (VARGHESE et al., 2002). Generally sibling coefficient values may be high in young orchards and during poor flowering years (KANG and LINDGREN, 1999).

A cumulative contribution curve can be used to quantify fertility variation in orchard trees (Fig. 1). The relation between proportion of trees and the accumulative gamete contribution would be a straight line in an ideal situation of equal contribution of all trees to the gamete pool (when sibling coefficient would be 1). The proportion of individuals contributing gametes determines the deviation from ideal situation and often a skewed trend of $20 \%$ of the most fertile trees contributing $55 \%$ gametes is observed in tropical tree stands (BILA et al., 1999). The orchards at coastal Pondy site (58\% for C. junghuhniana and $62 \%$ for C. equisetifolia) had values close to the reported trend. Inland orchards of both species showed more skewed trends due to greater variation in tree fertility. While C. equisetifolia orchard at Karunya had $70 \%$ gamete contribution from $20 \%$ trees, C. junghuhniana had many non-flowering trees at Panampally (inland site), that $20 \%$ of the trees contributed as much as $87 \%$ and $6 \%$ of the most fertile trees contributed $50 \%$ of gametes. This trend is evident in Fig. 1.

\section{Effective number and coancestry}

Inbreeding and coancestry levels of natural forest stand is assumed to be zero (or rather arbitrarily set as zero as a reference to investigate the rise caused by forest tree breeding and

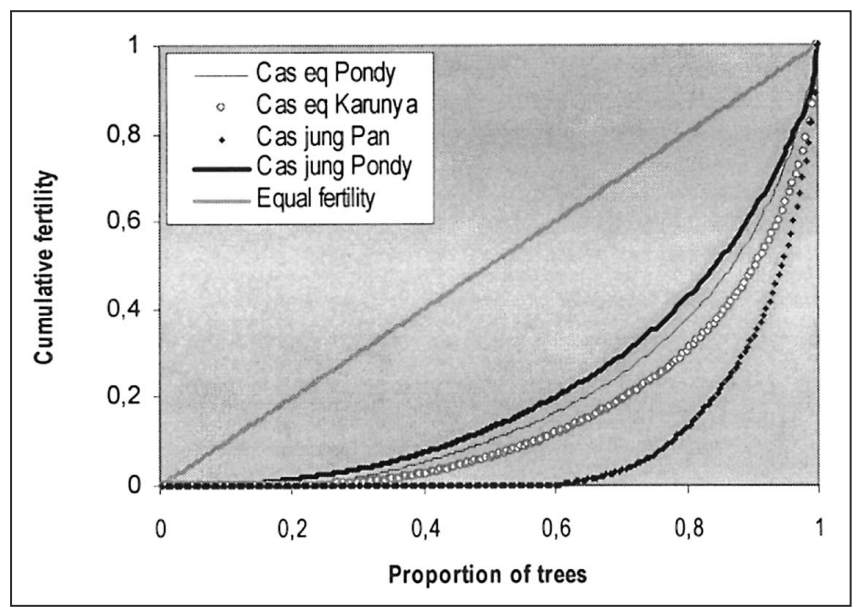

Figure 1. - Cumulative contribution to fertility (reproductive output) in different seedling seed orchards (Cas eq- C. equisetifolia orchards, Cas jung- $C$. junghuhniana orchards at different sites - Pondy, Panampally and Karunya). 
the establishment of seed orchards), and build up of inbreeding can result from relatedness of orchard trees or the relatedness in orchard crop resulting from high fertility differences and self fertilization in the orchard. Group coancestry of the seed crop from breeding population, (inland site, Karunya) where family identity is maintained, was computed as a function of the relatedness and fertility proportions of the orchard trees (LINDGREN and Mullin, 1998). The other three orchards converted from provenance trials were established from bulked seed collections of large number of trees and hence the trees were considered to be unrelated and non inbred as they are selections mostly from natural populations.

The group coancestry values are low for orchards in the coastal site (Table 4) even though these orchards have more trees than those established inland. This is mostly because of the lower fertility variation in this location. Coancestry values are 3 and 5 times higher in inland orchards of Casuarina equisetifolia and C. junghuhniana respectively compared to Pondy orchards. Though the percentage of fertile trees are more or less same in both C. equisetifolia orchards, the monoecious trees have two times more fertility in the coastal site and balanced sexual symmetry compared to inland trees. Monoecious trees in the coastal site produced almost the same quantity of male and female flowers as the dioecious trees but in the inland orchard, the dioecious trees had almost 6 times more male and $50 \%$ more female reproductive output (Table 4). The higher coancestry values of $C$. equisetifolia breeding seedling orchard at Karunya also result from the fact that the trees retained in the orchard are from 69 families which means that many trees in the orchard are related.

The gene diversity and relatedness situation concerning a seed orchard may be more understandable if expressed as an effective number. The effective number of individuals in an orchard is equivalent to status number $\left(N_{s}\right)$ if the trees in the orchard are non inbred and unrelated and is considered a characteristic of seed crop (LindGREN and MulLin, 1998). The two traits differ when related trees are considered as in the breeding population studied at Karunya, since the chances of related mating in the orchard is also considered. The orchards at coastal location maintain almost two times higher status number than the inland sites. This trend is also evident from the higher relative status number of coastal orchards. This study gives an indication that about $17-28 \%$ of the trees in inland location and $34 \%$ trees in coastal site contribute effectively in production of seed crop. Effective population size could vary between years, often increasing in good flowering years (KJAER, 1996).

Variance effective population size is a function of sibling coefficient and coancestry of orchard trees. Thus based on fertility differences and the resulting relatedness in orchard crop this parameter gives a measure of genetic drift in orchard progeny from the parent trees. Large variation in gamete contribution as seen in the inland $C$. junghuhniana plantation would result in low $N_{e}^{(v)}$ values (Table 4 ). Variance effective population size was at least 3 times higher in coastal site compared to inland locations in both species. Thus gene frequencies of parents and offspring differ more in inland orchards where fertility variation is high.

Seed crop from coastal and inland orchards would differ with regard to drift and coancestry level. Care should therefore be taken during seed collection from inland orchards to ensure that adequate seeds are collected from as many trees as possible and maintained separately prior to bulking to mitigate the effect of genetic drift and keep coancestry level as minimum as possible (KJAER and WELLENDORF, 1998).

\section{Gene diversity of seed crop}

The emphasis in most improvement programmes is gain. However in a first generation orchard where trees are in early stages of domestication, a more conservative strategy of maintaining adequate diversity would be necessary to sustain improvement in subsequent generations. A small effective population size would reduce diversity of seed crop leading to increased relatedness in progeny. Low effective population size indicates that genetic composition of the seed crop would be different from that of orchard trees (KANG and LINDGREN, 1998). If there are not many flowering trees in the orchard, a low effective to actual population size would lead to loss of diversity in seed crop. But if there is adequate number of fertile unrelated trees in the orchard, even if the effective population size is low, there may not be serious diversity concerns in the crop.

Loss of diversity occurs from increase in coancestry levels in orchard as a result of poor flowering in trees. Despite big difference in fertility, loss of diversity in inland orchards (1-2\%) is not very drastic. This ensures that there is still sufficient diversity to carry on to the next generation, as inbreeding levels are not very high. However for a newly introduced species, it would be desirable to obtain seeds with wide genetic base to be able to adapt to different environmental conditions. The essential difference between the two environments is the sexual behaviour of trees that influence the male and female fertilities. Even though the fertility of inland C. junghuhniana plantation is highly skewed, the reproductive contribution of unrelated trees ensures sufficient diversity in the orchard.

This study has not considered the variation in reproductive phenology of trees and there could be differences in simultaneous flowering. However reproductive output of trees and the variation between trees has a greater role in understanding the reproductive balance of orchard (EL-KASSABY et al., 1984). Female fertility estimation would be more accurate in this study as male inflorescences may fall compared to female cones which remain on trees even after seed shed.

\section{Implications in Casuarina breeding programme}

Conversion of genetic tests to seedling seed orchards marks the culmination of a generation of testing and selection in a breeding program for a short rotation crop as Casuarina (where rotation age is as low as four years). Thinning based on tree growth is done to enhance genetic gain and promote seed production in remaining trees. Fertility is not a major constraint in land races (VARGHESE et al., 2002) that have been domesticated over several generations in a region. Fertility differences have been reported between native populations and land races in Casuarina equisetifolia (LUECHANIMITCHIT, 2002). Newly introduced populations often show poor and delayed flowering in provenance trials in Asian countries (NAGARAJAN $e t$ al., 2001).

Managing the right proportion of sexes and sexual symmetry in monoecious Casuarina equisetifolia trees in different locations would require attention while selecting sites for orchard establishment. Sexual asymmetry may be considered beneficial to reduce selfing in orchards but the overall contribution of the tree gets reduced resulting in over - representation of the productive trees. Fertility would thus be a major parameter for evaluating breeding orchards. It would be wise to ensure that entries from land races are restricted to have adequate representation of outstanding provenances in the seed crop. Locating orchards in coastal environments would be a safe strategy in a first generation crop and care should be taken to collect seed from large number of trees. 
Information on the gamete contribution and effective population size of orchards is important when collecting seeds for breeding and afforestation programs. It has been seen that fertility and sexual pattern of trees are related to the provenance effects and poor flowering seedlots are consistently poor in different locations (NICODEMUs et al., 2001b) Thus effort should to be taken to see that certain promising provenances of $C$. equisetifolia like Thailand and Kenya (which have low fertility) are represented in the seed crop. Constrained seed collection, which ensures adequate seed from as many good trees as possible, would be a safe strategy to prevent diversity loss in seed crop (KANG et al., 2003b).

C. junghuhniana has shown good growth and high fertility in coastal region making it a promising species for the eastern coast of South India. The ability to produce a coppice crop after harvest (NICODEMUS et al., 2003) makes it particularly appealing to farmers. There is also adequate scope for promoting vegetative propagation in this species. But since resource-poor farmers do most of the planting, seed will continue to be the major planting material. Orchards in inland locations will need proper management strategies for promoting flowering to achieve the desired results from breeding. Further studies would be needed to test the performance of orchard progeny from different sites in actual plantation situations, as factors like seed viability and vigor also influence plant growth. In early stages of domestication of a species, tree growth and fertility may not be correlated (KANG et al., 2003a) which makes it extremely important to include fertility in evaluation of breeding populations. Keeping sibling coefficient levels below 3 would ensure acceptable effective population sizes in seed stands (KANG et al., 2003a). Hence locating seed orchards in sites conducive to flowering and seed production is considered a useful domestication strategy for exotic trees (ZoBEL et al., 1988).

\section{Acknowledgement}

International Foundation for Science, Sweden (IFS) supported this study by providing a research grant (D/3236-1) to MoHAN VARGHESE. The Casuarina breeding programme is coordinated in Asian countries by CSIRO, Australia.

\section{References}

Bila, A. D., Lindgren, D. and Muldin, T. J. (1999): Fertility variation and its effect on diversity over generations in a teak plantation (Tectona grandis L.f) Silvae Genet. 48 109-114.

El-Kassaby, Y. A., Fashler, A. M. K. and Sziklai, O. (1984): Reproductive phenology and its impact on genetically improved seed production in a Douglas fir seed orchard. Silvae Genet. 33: 120-125.

KANG, K. S. and LindGREN, D. (1998): Fertility variation and its effect on the relatedness of seeds in Pinus densiflora, $P$. thunbergii and $P$. koraiensis clonal seed orchards. Silvae Genet. 47: 196-201.

KANG, K. S and LINDGREN, D. (1999): Fertility variation among clones of Korean pine (Pinus koraiensis S. et Z.) and its implications on seed orchard management. For. Genet. 6: 191-200.

KANG, K. S., Lindgren, D. and Mullin, T. J. (2001): Prediction of genetic gain and gene diversity in seed orchard crops under alternative management strategies. Theor. Appl. Genet 103: 1099-1107.

Kang, K. S., Bila, A. D., Harju, A. M. and Lindgren, D. (2003a): Estimation of fertility variation in forest tree populations. Forestry 76(3): 329-344.

KANG, K. S., KJAER, E. D. and LindGREN, D. (2003b): Balancing gene diversity and nut production in Corylus avellana L. collections. Scan. J. For. Res. 18: 118-126.
KJAER, E. D. (1996): Estimation of effective population number in a Picea abies (Karst.) seed orchard based on flower assessment. Scand. J. For. Res. 11: 111-121.

KJAER, E. D. and WELLENDORF, H. (1998): Variation in flowering and reproductive success in a Danish Picea abies (Karst.) seed orchard. Forest Genetics 4: 181-188.

LindGREN, D. and MulLin, T. J. (1998): Relatedness and status number in seed orchard crops. Can. J. For. Res. 28: 276-283.

LueChanimitchit, P. (2002): Sex of Casuarina equisetifolia subsp. equisetifolia in an international provenance trial in Thailand. NFT News 5(1): 5-6.

LUECHANIMITCHIT, P. and LuANGVIRIYASAENG, V. (1996): Study of sex ratios and relationship between growth and sex in Casuarina equisetifolia. In: PinYoPUSARERK, K., TURnBUlL, J.W., and Midgley, S. J. (eds.), 1996: Recent Casuarina research and development. Proceedings of the Third International Casuarina Workshop, Da Nang, Vietnam. 4-7 March 1996. CSIRO, Canberra. pp. 30-32.

Nagarajan, B., Nicodemus, A., Varghese, M. and Sivakumar, V. (2001): Reproductive biology of Casuarina equisetifolia. In: Gurumurthi, K., Nicodemus, A. and SiddaPPA (eds.): Casuarina Improvement and Utilization. Institute of Forest Genetics and Tree Breeding, Coimbatore, India. pp 63-68.

Narayanan, C., Dudzinski, M. J., Sharma, J. K. and Mohanan, C. (1996): The extent, recognition and management of Casuarina blister bark disease. In: PINYOPUSARERK, K., TURNBULL, J.W. and Midgley, S. J. (eds.): Recent Casuarina Research and Development. Proceedings of the Third International Casuarina Workshop, Da Nang, Vietnam, 4-7 March 1996, CSIRO, Australia. pp. 74-79.

Nicodemus, A., Varghese, M., Narayanan, C. and Ravi, N. (2001a): Utilization of Casuarina genetic resources in India. In: Gurumurthi, K., Nicodemus, A. and SiddaPPA (eds.): Casuarina Improvement and Utilization. Institute of Forest Genetics and Tree Breeding, Coimbatore, India. pp 177-184.

Nicodemus, A., Varghese, M., Narayanan, C. and Ravi, N. (2001b): Genetic improvement of Casuarina equisetifolia through selection and breeding. In: GURUMURTHI, K., NICODEMUS, A. and SIDDAPPA (eds.): Casuarina Improvement and Utilization. Institute of Forest Genetics and Tree Breeding, Coimbatore, India. pp 3-13.

Nicodemus, A., Varghese, M. and Nagarajan, B. (2003) Coppicing ability of Casuarina junghuhniana Miq. provenances. Myforest 39(4): 359-363.

PINYOPUSARERK, K. (1996): A breeding programme for Casuarina equisetifolia in India. CSIRO Forestry and Forest Products, Canberra, Australia. 39p.

PinYoPUSARERK, K. and Boland, D. J. (1990): Casuarina junghuhniana - an Indonesian species of promise for the tropics. In: El-LaKanY, M. H., TuRnBull, J.W. and BREWBAKER, J. L. (eds.): Advances in Casuarina Research and Utilization. Desert Development Centre, American University in Cairo, Cairo, Egypt. pp. 202-212

PinyopUsareRK, K. and Williams, E. R. (2000): Range-wide provenance variation in growth and morphological characteristics of Casuarina equisetifolia grown in Northern Australia. Forest Ecol. Manage. 134: 219-232.

Pinyopusarerk, K., Williams, E. R., Luangviriyasaeng, V. and PURIYAKORN, B. (1996): Geographical variation in growth and morphological traits of Casuarina equisetifolia. In: PINYoPUSARERK, K., Turnbull, J.W. and Midgley, S. J. (eds.): Recent Casuarina Research and Development. Proceedings of the Third International Casuarina Workshop, Da Nang, Vietnam, 4-7 March 1996, CSIRO, Australia. pp. 143-151.

Varghese, M., RaVi, N., Son, S. G. and Lindgren, D. (2002): Variation in fertility and its impact on gene diversity in a seedling seed orchard of Eucalyptus tereticornis. In: WEI, R. P. and XU, D. (eds.): Eucalyptus plantations - Research, Management and Development. World Scientific, Singapore. pp 111-126.

Warrier, K. C. S., Ajtth Kumar, K. G., Warrier, R. R. and GURUMURTHI, K. (2001): Studies on sexual variation in clones of Casuarina equisetifolia Forst. Indian Forester 127: 865-870.

Zobel, B., WyK, G. VAN and StÅHL, P. (1988): Exotic Forestry. John Wiley \& Sons, New York. 